Article

\title{
Adapting Cultural Heritage to Climate Change Risks: Perspectives of Cultural Heritage Experts in Europe
}

\author{
Elena Sesana $^{1}$ (1), Alexandre S. Gagnon ${ }^{1}$ (D), Chiara Bertolin ${ }^{2}$ (1) and John Hughes ${ }^{1, *(1)}$ \\ 1 School of Computing, Engineering and Physical Sciences, University of the West of Scotland, High St, \\ Paisley PA1 2BE, UK; elena.sesana@uws.ac.uk (E.S.), alexandre.gagnon@uws.ac.uk (A.S.G.) \\ 2 Department of Architectural Design History and Technology, Norwegian University of Science and \\ Technology (NTNU), Alfred Getz vei 3, 7491 Trondheim, Norway; chiara.bertolin@ntnu.no \\ * Correspondence: John.Hughes@uws.ac.uk; Tel.: +44-(0)-141-848-3268
}

Received: 6 July 2018; Accepted: 8 August 2018; Published: 14 August 2018

\begin{abstract}
Changes in rainfall patterns, humidity, and temperature, as well as greater exposure to severe weather events, has led to the need for adapting cultural heritage to climate change. However, there is limited research accomplished to date on the process of adaptation of cultural heritage to climate change. This paper examines the perceptions of experts involved in the management and preservation of cultural heritage on adaptation to climate change risks. For this purpose, semi-structured interviews were conducted with experts from the UK, Italy, and Norway as well as a participatory workshop with stakeholders. The results indicate that the majority of interviewees believe that adaptation of cultural heritage to climate change is possible. Opportunities for, barriers to, and requirements for adapting cultural heritage to climate change, as perceived by the interviewees, provided a better understanding of what needs to be provided and prioritized for adaptation to take place and in its strategic planning. Knowledge of management methodologies incorporating climate change impacts by the interviewees together with best practice examples in adapting cultural heritage to climate change are also reported. Finally, the interviewees identified the determinant factors for the implementation of climate change adaptation. This paper highlights the need for more research on this topic and the identification and dissemination of practical solutions and tools for the incorporation of climate change adaptation in the preservation and management of cultural heritage.
\end{abstract}

Keywords: adaptation; climate change; cultural heritage; management; conservation

\section{Introduction}

Our tangible cultural heritage is threatened by gradually shifting weather patterns and extreme events. An increase in temperature together with changes in precipitation, relative humidity, and wind, for instance, can negatively impact on the materials comprising cultural heritage assets. This is because a change in average climatic conditions as well as changes in the frequency and intensity of severe weather events can affect the biological, chemical, and physical mechanisms leading to degradation of the assets [1-5]. This includes an increase in the freeze-thaw cycle in northern Europe, extreme heat and droughts in the Mediterranean region, the overall decrease in summer precipitation in Europe, and an increase in winter storms and heavy precipitation events in the Atlantic region. In addition, cultural heritage sites in coastal regions are particularly at risk of sea-level rising (SLR) and the occurrence of storm surges while natural hazards such as floods, landslides, earthquakes, volcanoes, and fire can also have devastating impacts on cultural heritage assets. As the outputs from global climate models project that climatic changes will grow larger over the current century with the magnitude of the projected change dependent on the selected path of greenhouse gas (GHG) emissions and the 
model selected, strategies need to be developed to reduce the negative consequences of climate change on sites of historical value in addition to mitigate climate change by curtailing GHG emissions.

The United Nations Framework Convention on Climate Change (UNFCCC) established the need to address both mitigation and adaptation to climate change [6]. Hence, there are two strands to the climate change challenge. Mitigation encompasses measures and activities aimed at reducing GHG emissions or enhancing the sinks of such gases, whilst adaptation refers to any adjustments in a system in response to the actual or projected climatic stimuli $[7,8]$, including changes in socio-environmental processes, perceptions, practices, and actions to reduce potential damages or to take advantage of new opportunities that may arise [9]. Mitigation has traditionally been given more attention in climate change research and policy than adaptation [10-13]. Nonetheless, there has been increasing interest in adaptation research since the late 1990s due to the recognition that the climate is already changing and that adaptation to the already unavoidable impacts is crucial [13,14]. In the field of cultural heritage, mitigation can involve improving the energy efficiency of historical buildings, for instance, while building a sea wall to protect coastal heritage sites from storm surges and SLR is an example of adaptation to climate change risks.

This paper focuses on adapting cultural heritage to climate change risks and is limited to the immovable and tangible cultural heritage, for example, historical buildings, monuments, and archaeological sites. The objectives of this paper are as follows:

- To understand how climate change adaptation is considered by experts in cultural heritage preservation in Europe. This includes determining the perspectives of these experts specifically on the requirements for, and opportunities and barriers to, adaptation, and the determinant factors for the implementation of adaptation efforts.

- To identify current examples of best practice in the management and practical site-level strategies and methodologies for adapting cultural heritage to climate change.

\section{Adapting Cultural Heritage to Climate Change Risks}

Previous studies have focused on assessing the impacts of climate change on cultural heritage sites in Europe [1-5,15], with limited research on adaptation. Efforts in the area of adaptation are yet limited to the dissemination of guidelines and recommendations for implementing adaptation measures [1,16-25], the identification of the determinants of adaptive capacity [26], and the identification of the barriers to adaptation [27-30]. Sabbioni et al. [1,16] developed guidelines for adapting the European cultural heritage to climate change impacts, which were later adopted by the Italian Strategic Agenda [31,32]. These included strategies for both physical adaptation and for adjusting management practices. Examples of the latter include improving the monitoring, maintenance, and preparedness to floods and landslides at cultural heritage sites [1,16]. Heathcote et al. [17] described the adaptive measures suggested in the Historic England climate change adaptation plan to cope with the impacts of climate change on cultural heritage in England, for example, developing approaches to deal with change and loss. Haugen and Mattson [18] investigated the impacts of climate change on cultural heritage in Norway, and recommended adaptive measures to deal with the risks identified. Also in Norway, Grøntoft [23] discussed options for adapting the surface of heritage material and the facades of heritage buildings to the impacts of climate change, including encouraging the adoption of adaptive measures that preserve building surfaces, incorporating climate change projections in building regulations, and developing new technologies to adapt buildings to future climatic conditions.

In addition to providing adaptive solutions to climate change impacts, some studies have examined the determinants of adaptive capacity in the field of cultural heritage, the role of tourism in supporting adaptation efforts, and key issues associated with adaptation of cultural heritage to climate change $[25,26]$. Phillips [26] investigated the adaptive capacity to climate change at cultural heritage sites and identified access to information, authority, resources, cognitive factors, leadership, and learning capacity as the key determinants. Hall [25] and Hall et al. [24] gave insight into the role of tourism in adapting cultural heritage to climate change. Furthermore, Hall et al. [24] identified 
key themes in dealing with the consequences of climate change for cultural heritage, such as the importance of using integrated approaches in adaptation and preserving the values interconnected with the local heritage through consultation with stakeholders that live and work within heritage sites, the need for a unified approach in cultural heritage preservation, and dealing with the paucity of funding for climate change adaptation.

Other studies have analysed climate change adaptation strategies for specific heritage typologies such as archaeological sites and historical districts located in coastal regions. A recurring theme emerging from these studies is the need to strengthen monitoring and maintenance and increase risk-preparedness and the dissemination of know-how when considering adaptation of cultural heritage to climate change. Cassar [19] investigated the impacts of climate change on archaeological sites and suggested adopting solutions that are sensibly designed to the specific conditions of the site after a long-term programme of monitoring and maintenance. She also deliberated on the adaptive solution adopted for the Megalithic Temples, a World Heritage Site (WHS) located in Malta. Additionally, Cassar [19] summarised the adaptation measures suggested by the UN Educational, Scientific and Cultural Organization (UNESCO) and by the International Council On Monuments and Sites (ICOMOS), who recommend increasing research, knowledge, education, engagement, the upgrading of management plans-including risk assessments-and monitoring procedures to increase the resilience of the sites. Pollard-Belsheim et al. [20] investigated the effectiveness of existing adaptation strategies to preserve coastal archaeological sites with a focus on a range of adaptation solutions such as watertight barriers, wooden breakwaters, and gabion rock wall. Climate change adaptation solutions to archaeological sites were also studied by Carmichael et al. [21] in indigenous communities in Australia. In the Republic of Tartasan in Russia, Usmanov et al. [33] suggested adaptation measures to preserve coastal archaeological sites from coastal erosion such as building breakwaters, changes in land use and planting trees. Nicu [34] also suggested planting trees to stabilise slopes as an adaptation measure to preserve the archaeological and paleontological sites of northeastern Romania, a region susceptible to landslides, a natural hazard whose occurrence could be affected by climate change. Fatorić and Seekamp [22] examined an approach to support decision-making by promoting climate change adaptation through the sharing of information and better engagement amongst stakeholders in the historical districts of the coast of North Carolina in the United States (US).

Until now, less research has been conducted on the identification of the barriers to adapting our cultural heritage to climate change [27-30] and in considering geological hazards in the assessment of vulnerability to inform the adaptation process. Phillips [27] investigated whether climate change is considered in the management plans of WHS in the United Kingdom (UK) and identified issues arising from its consideration, notably the lack of detailed information from climate change scenarios and the uncertainty associated with them, as well as the lack of resources, knowledge, and skills available. Also in the UK, it was noted that knowledge of geological and geomorphological processes can improve our understanding of the risk of natural hazards on WHS and thereby inform adaptation to climate change [35]. However, natural processes have often been ignored in previous assessments of vulnerability and the inclusion of geological hazards such as landslides and groundwater flooding in vulnerability assessments is limited [36]. Fatorić and Seekamp [28] identified 16 barriers to adaptation of cultural heritage to climate change in the Southeast of the US, which they grouped into three main categories: institutional barriers (e.g., lack of political commitment), technical barriers (e.g., lack of technical expertise), and financial barriers (e.g., lack of funding). The barriers to adaptation identified by Carmichael et al. [29] at cultural heritage sites in Australia were related to governance and compatibility with current management frameworks. Casey [30] identified two categories of barriers to adapt cultural heritage sites in three US National Parks to climate change: institutional barriers, which result from existing structures and frameworks, and conceptual barriers, such as problems in prioritizing the cultural resources to be preserved and adapted, together with challenges in managing those resources. Casey [30] also identified potential solutions to overcome those barriers, for example, including climate change in regulations and management plans. 
The issue of adaptation to climate change began to be seriously considered only since the publication of the UNFCCC in the 1990s [11,37]. Climate change adaptation is thus a relatively new challenge and this is particularly the case in the field of cultural heritage. The impacts of climate change on cultural heritage were first mentioned in the chapter on Europe of the Fifth Assessment Report (AR5) of the Intergovernmental Panel on Climate Change (IPCC) in 2014. At the 21st session of the Conference of the Parties (COP21) of the UNFCCC in Paris, a number roundtable discussions on the topic of climate change and cultural heritage were organized [38], and, following the adoption of the Paris Agreement, the World Heritage Committee of UNESCO, at their annual session in 2017 in Krakow, Poland, noted the pressing issue of climate change impacts on World Heritage properties and requested that the UNESCO World Heritage Centre support State Parties in managing climate change impacts and in strengthening collaboration with the UNFCCC and the IPCC [39]. The World Heritage Committee is responsible for the World Heritage Convention and consists of representatives from 21 of the State Parties, which are elected by the General Assembly. This led to the IPCC consulting with UNESCO to identify topics to be incorporated as part of AR6 to be published in 2021. Climate change impacts were only briefly mentioned in AR5 and the impacts presented in the report were mainly the results of initiatives funded by the European Commission (EC) over the last 15 years such as the Noah's Ark (2003-2007) and Climate for Culture (2009-2015) projects. These projects focused on the threats of climate change on cultural heritage with limited attention given to adaptation of cultural heritage to climate change.

There are only a few well-documented cases of adaptation of cultural heritage to climate change with most research focusing on the identification of the risks of climate change and the provision of guidelines and suggestions to adapt to those risks. A limited number of studies have examined the barriers to adapt cultural heritage sites to climate change, albeit the literature on this topic is not yet comprehensive [40]. Heritage managers need to mitigate against the impacts of current changes in climate, including changes in the frequency and intensity of extreme events [1], but also require awareness of the potential impacts of climate change. For this reason, it is recommended to include climate change within management plans and decision-making strategies $[15,26]$. A number of questions remain insufficiently addressed in the literature, notably, how do experts involved in the preservation of cultural heritage consider climate change? Is climate change currently included in the management of heritage sites and, if so, how? What are the opportunities and limitations in adapting cultural heritage to climate change? The answers to these questions are essential for the development of adaptation measures and to identify future research directions.

\section{Materials and Methods}

Semi-structured interviews were conducted in three European countries: the UK, Italy and Norway. The interviews centered on the following four questions: (1) is adaptation of cultural heritage to climate change possible? (2) Are you aware of any example(s) of management methodologies to mitigate the impacts of climate change on cultural heritage? (3) Are you aware of best practice examples in adapting cultural heritage to climate change? (4) What are the determinant factors for implementing adaptation of cultural heritage to climate change? A total of 45 interviews were conducted with experts involved in the preservation of cultural heritage. The interviewees were categorized into three main groups: 19 academics and researchers from universities and research centers in the UK, Italy, and Norway, including investigators having worked or currently working on EU projects focusing on the theme of climate change and cultural heritage; 12 members of governmental institutions working on the preservation of cultural heritage; and 14 people involved with the management of UNESCO WHS, such as managers, coordinators, and professionals. The interviewed experts on cultural heritage preservation have diverse backgrounds and specializations, including anthropologists, archaeologists, architects, conservation scientists, geologists, biologists, heritage site managers and coordinators, sustainability officers, and urban planners. The interviews were audio recorded and subsequently 
transcribed and analyzed using the NVivo software. (Version 11, QSR International (UK) Limited, Daresbury, Cheshire, UK).

Since there is limited research on adaptation of cultural heritage to climate change, the adoption of a qualitative methodology using semi-structured interviews was considered the most appropriate. Michalski and Bearman [41] noted the advantage of semi-structured interviews when there is inadequate knowledge on a particular topic. The interviews were complemented with a critical analysis of the grey literature such as reports and documents gathered from the interviewees, websites of the institutions employing them or that they recommended, and books and journal articles. The former included existing management plans, national policies and guidelines, regional documents and brochures. A one-day workshop titled: "Vulnerability and adaptation of cultural heritage to climate change. Supporting decision-making in adapting cultural heritage sites to climate change" was also organized to gather further information on experts' perceptions and also to allow for the exchange of information amongst participants. The workshop took place on 22 March 2018 at the New Lanark UNESCO WHS and was attended by 22 experts in cultural heritage preservation, including participants from academia, government institutions, and managers of heritage sites. The workshop included a site visit, a number of presentations, and an interactive part. The latter consisted of three facilitated roundtable discussions on issues related to the vulnerability and adaptation of different WHS to climate change. With regard to adaptation, the discussion particularly focused on the challenges of adaptation and opportunities for the implementation of adaptation strategies. The methodological approach selected for this study, which involved stakeholders' interviewees and a participatory workshop, has previously been used in climate change adaptation research [42,43]. Ethical approval was sought and obtained through the University of the West of Scotland procedure.

\section{Results}

The first part of the investigation focused on understanding the participants' perceptions on the possibility of adapting cultural heritage to climate change. How do they feel about it? Is adaptation of cultural heritage to a changing climate a challenge that can be dealt with? What are their doubts and perplexities on this topic? The majority of the participants agreed that adaptation of cultural heritage to climate change is possible (Table 1). Some interviewees were not fully confident about this possibility and a few did not answer this question. No interviewees indicated that adaptation is not possible. The interviewees' answers on the possibility of adapting cultural heritage to climate change were coded into three main categories to highlight their perceptions on the 'opportunities', 'requirements', and 'barriers' in adapting cultural heritage to climate change. Table 2 summarizes those 'opportunities', as identified by the interviewees, which were classified according to the following themes: 'moving from reactive to proactive adaptation', 'working on mitigation and adaptation together', 'strengthening monitoring and maintenance', 'making adaptive change', 'increase collaboration', and 'positivity'. The 'requirements' for more information and resources to make adaptation possible, as expressed by the interviewees, are included in Table 3. The interviewees also identified a number of barriers to adaptation, which were classified into the following themes: 'diversification', 'uncertainty', 'resignation', 'loss', 'preserving values, integrity and authenticity', and 'financial resources' (Table 4).

Table 1. Answer of the participants to the question "Can cultural heritage be adapted to future climate change?".

\begin{tabular}{cccc}
\hline Yes & No & Yes and No & No Answer \\
\hline $42 \%$ & $0 \%$ & $31 \%$ & $27 \%$ \\
\hline
\end{tabular}


Table 2. Opportunities for adapting cultural heritage to climate change.

\begin{tabular}{|c|c|c|}
\hline Opportunities & Interviewee & Quotation \\
\hline \multirow[t]{2}{*}{$\begin{array}{l}\text { From reactive to } \\
\text { proactive adaptation }\end{array}$} & Academic & $\begin{array}{l}\text { "Yes, it can be adapted. Considering the long-term perspective (...) As the climate } \\
\text { becomes wetter with more storms it is going to be even more work to maintain the heritage } \\
\text { as it is and increase (...) resilience. ( . . ) How to move from reacting to small problems } \\
\text { to consider long-term perspectives? Adapting in (the) long perspective involves choices." }\end{array}$ \\
\hline & Researcher & $\begin{array}{l}\text { "We need to adapt our thinking to climate change. We need to think in longer terms than } \\
\text { five administration years. The problem is thinking that everything can be managed in the } \\
\text { short term." }\end{array}$ \\
\hline \multirow{3}{*}{$\begin{array}{l}\text { Mitigation and } \\
\text { adaptation }\end{array}$} & Academic & "A balance (is needed) between mitigation and adaptation. We must balance both." \\
\hline & Academic & "I think that there is too much emphasis on adaptation instead of mitigation." \\
\hline & Academic & $\begin{array}{l}\text { "With climate change the focus has been more on responding, on one hand there is adaptation, } \\
\text { but there is more on mitigation, and trying to make the buildings more energy efficient." }\end{array}$ \\
\hline \multirow{4}{*}{$\begin{array}{l}\text { Monitoring and } \\
\text { maintenance }\end{array}$} & Academic & $\begin{array}{l}\text { "There is a need to monitor change in cultural heritage. Monitoring is very important, } \\
\text { and to strengthen maintenance." }\end{array}$ \\
\hline & Researcher & $\begin{array}{l}\text { "Maintenance is fundamental E necessary. Restoration is the last thing to be done. First you } \\
\text { examine. Then therapy, and last you perform surgery. You do not wait until it falls down before } \\
\text { intervening. Study more situations, do maintenance once the problem is clear and involve more } \\
\text { expertise. There are no experts about this in the responsible authorities." }\end{array}$ \\
\hline & $\begin{array}{l}\text { Manager of } \\
\text { heritage site }\end{array}$ & $\begin{array}{l}\text { "Most traditional buildings are built in a very sensible way, they are built with natural } \\
\text { materials, (they can be adapted) if they are maintained." }\end{array}$ \\
\hline & $\begin{array}{l}\text { Conservation } \\
\text { scientist }\end{array}$ & "The best that we can do is to keep up proper maintenance to deal with increased rainfall." \\
\hline \multirow{4}{*}{$\begin{array}{l}\text { Make 'adaptive' } \\
\text { change }\end{array}$} & $\begin{array}{l}\text { Member of } \\
\text { government } \\
\text { institution }\end{array}$ & $\begin{array}{l}\text { "Yes, I think so. (...) Something has to change. In historical buildings that cannot handle } \\
\text { the increase in rainfall realistic change should be possible, so they can still be used." }\end{array}$ \\
\hline & $\begin{array}{l}\text { Manager of } \\
\text { WHS }\end{array}$ & $\begin{array}{l}\text { "We have to think... how are we going to take actions? That may be things like } \\
\text { recognising that we need to improve the drainage system. Potentially changing the } \\
\text { detailing on the roofs. I think that will probably sensible if people now would change the } \\
\text { size of the gutters, when the opportunity arises. There are small things that will change the } \\
\text { appearance of the building but I would say that look after it is better. I think there is a kind } \\
\text { of better maintenance looking at what all kind of changes would be." }\end{array}$ \\
\hline & Academic & $\begin{array}{l}\text { "With climate change you are expected to see various changes taking place. (... ) } \\
\text { Buildings have to be adapted to meet the environmental changes (...) we may try to keep } \\
\text { the same look but you will not be able to just leave it like it was. (...) But on the other } \\
\text { hand you can still retain the basic elements of the buildings even if there are changes. } \\
\text { You can still have the facade (...) but you cannot pretend that there has not been change } \\
\text { when it is been adapted." }\end{array}$ \\
\hline & $\begin{array}{l}\text { Member of } \\
\text { government } \\
\text { institution }\end{array}$ & $\begin{array}{l}\text { "In terms of climate change adaptation and resilience it is need to be changes to that design } \\
\text { in terms of gutters and mortars." }\end{array}$ \\
\hline \multirow{6}{*}{ Increase collaboration } & Academic & $\begin{array}{l}\text { "If experts work together maybe it is possible to find solutions. Collaboration is } \\
\text { fundamental. Nowadays the sector is abandoned to itself. Points of view must be shared." }\end{array}$ \\
\hline & $\begin{array}{l}\text { Manager of } \\
\text { WHS }\end{array}$ & $\begin{array}{l}\text { "We have close collaboration with other organizations that are very beneficial for everyone } \\
\text { on a wider level." }\end{array}$ \\
\hline & $\begin{array}{l}\text { Manager of } \\
\text { WHS }\end{array}$ & $\begin{array}{l}\text { "I think that the international community need to work together. To raise the collaboration } \\
\text { between countries and the level of each country. If a country has more welfare than another, } \\
\text { it is easier to do something. ( . . ) (like) sharing resources and knowledge." }\end{array}$ \\
\hline & $\begin{array}{l}\text { Manager of } \\
\text { WHS }\end{array}$ & $\begin{array}{l}\text { "The most positive impact I could imagine from climate change is if people are forced to } \\
\text { work together." }\end{array}$ \\
\hline & Researcher & "Involving more expertise, it would be essential to have a team ..." \\
\hline & Academic & $\begin{array}{l}\text { "(...) participation between different sectors in contributing to the safeguarding of } \\
\text { heritage and (...) communication and collaboration between different sectors: academic } \\
\text { and political." }\end{array}$ \\
\hline \multirow{3}{*}{ Positivity } & $\begin{array}{l}\text { Member of } \\
\text { government } \\
\text { institution }\end{array}$ & $\begin{array}{l}\text { "There is already this sensibility (to climate change or to adaptation) in some institutions. } \\
\text { I am sure that it can be and must be done and that there is the sensibility to do it." }\end{array}$ \\
\hline & Academic & "I think it is possible if we work together." \\
\hline & $\begin{array}{l}\text { Member of } \\
\text { governmental } \\
\text { institution }\end{array}$ & "I think generally yes. (... ) I think that it is possible as long as you do the right things." \\
\hline
\end{tabular}


Table 3. Requirements for adapting cultural heritage to climate change.

\begin{tabular}{|c|c|c|}
\hline Requirements & Interviewee & Quotation \\
\hline \multirow{2}{*}{$\begin{array}{l}\text { Information on values, } \\
\text { integrity and } \\
\text { authenticity }\end{array}$} & Academic & $\begin{array}{l}\text { "How many changes can you make? How much adaptation can be done to maintain the } \\
\text { integrity? I think it has to be incorporated into management plans and it is not } \\
\text { incorporated right now." }\end{array}$ \\
\hline & Academic & $\begin{array}{l}\text { "You have to do, in some cases, more dramatic changes in the building even if it is cultural } \\
\text { heritage but this depends about the values that cultural heritage has." }\end{array}$ \\
\hline \multirow{2}{*}{ Resources } & $\begin{array}{l}\text { Manager of } \\
\text { heritage site }\end{array}$ & $\begin{array}{l}\text { "I hope so. It is just a matter of resources. If you do not have resources you do nothing. } \\
\text { Resources must be given but you need a national plan that foresees a self-sufficiency and a } \\
\text { return on these interventions." }\end{array}$ \\
\hline & $\begin{array}{l}\text { Manager of } \\
\text { heritage site }\end{array}$ & $\begin{array}{l}\text { "Yes, we certainly can. If there are resources made available to help the plans for the future. } \\
\text { (...) We need to articulate what the problems are (...) and have more funding for } \\
\text { research and for making people work in this area." }\end{array}$ \\
\hline
\end{tabular}

Table 4. Challenges in adapting cultural heritage to climate change.

\begin{tabular}{|c|c|c|}
\hline Barriers & Interviewee & Quotation \\
\hline \multirow{4}{*}{ Diversification } & Academic & $\begin{array}{l}\text { "I think that the situation is too diversified that it is not possible to speak about such a big } \\
\text { group of cultural heritage" }\end{array}$ \\
\hline & Biologist & "Well, it depends, on the specific geographic contexts" \\
\hline & Anthropologist & $\begin{array}{l}\text { "I guess it would depend on the type of change happening here. It probably depends on the } \\
\text { site. (...) If it is coastal there are problems." }\end{array}$ \\
\hline & Academic & $\begin{array}{l}\text { "I think that there is some cultural heritage that can be adapted and some that cannot be } \\
\text { adapted. An example is a structure failing on a coastline that is eroding. In some cases it is } \\
\text { not possible to move it. Also, in the Arctic where the permafrost is melting." }\end{array}$ \\
\hline \multirow{3}{*}{ Uncertainty } & $\begin{array}{l}\text { Coordinator } \\
\text { of heritage } \\
\text { site }\end{array}$ & $\begin{array}{l}\text { "It depends on how climate change will be. It is a matter of when we will face the situation. } \\
\text { There is not a } 100 \% \text { certainty ..." }\end{array}$ \\
\hline & $\begin{array}{l}\text { Sustainability } \\
\text { officer of } \\
\text { heritage site }\end{array}$ & $\begin{array}{l}\text { "The problem with adaptation is that we have to cope with problems that are not visible } \\
\text { really often." }\end{array}$ \\
\hline & Academic & $\begin{array}{l}\text { "Climate change has not been quantified so I would not be able to tell exactly that this area } \\
\text { needing more attention." }\end{array}$ \\
\hline \multirow{3}{*}{ Resignation } & $\begin{array}{l}\text { Sustainability } \\
\text { officer of } \\
\text { heritage site }\end{array}$ & $\begin{array}{l}\text { "When we look at different types of assessment, every site is different. ( . . For ( . . ) } \\
\text { most of the places apart from the coastal areas it is actually possible }(\ldots) \text { (but) ( . . ) if we } \\
\text { continue to do as we do now we will arrive to a point that is not possible to adapt anymore." }\end{array}$ \\
\hline & $\begin{array}{l}\text { Manager of } \\
\text { heritage site }\end{array}$ & $\begin{array}{l}\text { "Lots of these building were original stone works but they were coated in lime. ( ... ) The } \\
\text { reason why we don't do that these days is because we are too lazy to maintain it. ( . . .) If } \\
\text { we recoat the lime mortar, we will get dirty every couple of years so we have to paint it ..." }\end{array}$ \\
\hline & $\begin{array}{l}\text { Conservator } \\
\text { scientist }\end{array}$ & $\begin{array}{l}\text { "Cultural heritage doesn't adapt itself. Is the things that we can do for trying to protect it } \\
\text { from rainfall. (...) There is not so much that we can do. About roofs and gutters we can } \\
\text { improve that situation. But with ruins of buildings there is not so much that we can do for } \\
\text { them. There is not so much that we can do for rising sea level. If you get increased coastal } \\
\text { erosion there are few places where you can make interventions like protective sea walls and } \\
\text { barriers..." }\end{array}$ \\
\hline \multirow{3}{*}{ Loss } & $\begin{array}{l}\text { Member of } \\
\text { governmental } \\
\text { institution }\end{array}$ & $\begin{array}{l}\text { "I think that something will be lost. Definitely. And we do not have the resources to adapt } \\
\text { everything. I think there are difficult decisions to be made." }\end{array}$ \\
\hline & Academic & $\begin{array}{l}\text { "For sure ... for the most appreciated monuments you can do something. But our cultural } \\
\text { heritage it is so modest; it is timber, which is really vulnerable to biodegradation and } \\
\text { dependent on climatic conditions. I am not sure on how much we can do with the big } \\
\text { majority of timber houses. I think that we need to accept the loss. Climate change will speed } \\
\text { up the decay of cultural heritage." }\end{array}$ \\
\hline & $\begin{array}{l}\text { Conservator } \\
\text { scientist }\end{array}$ & $\begin{array}{l}\text { "A lot of coastal sites are just going to be lost, because we do not have the resources to } \\
\text { protect them." }\end{array}$ \\
\hline
\end{tabular}


Table 4. Cont

\begin{tabular}{|c|c|c|}
\hline Barriers & Interviewee & Quotation \\
\hline \multirow{5}{*}{$\begin{array}{l}\text { Values, integrity and } \\
\text { authenticity }\end{array}$} & Academic & $\begin{array}{l}\text { "As a functional building yes. But if you take in consideration the history and the } \\
\text { authenticity..." }\end{array}$ \\
\hline & Academic & $\begin{array}{l}\text { "You will need to make changes to it as well. You will not be able to preserve it exactly how } \\
\text { it is because of increasing requirements." }\end{array}$ \\
\hline & $\begin{array}{l}\text { Member of } \\
\text { governmental } \\
\text { institution }\end{array}$ & $\begin{array}{l}\text { "There are certainly a couple of Neolithic sites ... that have been moved. So imagine (an } \\
\text { archaeological site), what do you think that this is from a philosophical point of view? You } \\
\text { made a new fake (site)." }\end{array}$ \\
\hline & Academic & $\begin{array}{l}\text { "You cannot build all coastline defences. There is not just the buildings there is also the } \\
\text { natural landscape. There are no easy answers." }\end{array}$ \\
\hline & $\begin{array}{l}\text { Manager of } \\
\text { WHS }\end{array}$ & $\begin{array}{l}\text { "I think that we need to be careful. (... ) If you change the natural balance of something } \\
\text { you can have other effects, so you have to be really careful when you do interventions like } \\
\text { that. Also you never want to lose the original fabric." }\end{array}$ \\
\hline \multirow[t]{2}{*}{ Financial resources } & Academic & $\begin{array}{l}\text { "Depends on the scale of event. If we think about the coastal erosion in archaeological sites, } \\
\text { there are things that we can try to do, like build defences. But they will be very costly. } \\
\text { We record with laser scanner technology. We move the thing? It is very difficult." }\end{array}$ \\
\hline & $\begin{array}{l}\text { Conservation } \\
\text { scientist }\end{array}$ & $\begin{array}{l}\text { "There is a lot of coastline and vulnerable sites, not just properties that are in care, } \\
\text { but archaeological sites, where there isn't money or resources to protect all of them." }\end{array}$ \\
\hline
\end{tabular}

The second part of the investigation focused on the interviewees' awareness of existing assessment frameworks for adaptation and best practice to preserving cultural heritage from the threats of climate change. The majority of the interviewees were not aware of strategies considering climate change adaptation in the management of cultural heritage assets and sites (Table 5). The few strategies that were mentioned are to the work done by UNESCO, Historic Environment Scotland (HES), and the guidelines of the Italian national strategic agenda (Table 6), as Italy and France are two countries that currently include cultural heritage in their National Adaptation Plan to climate change [38]. HES is the public body for the investigation, care, and promotion of Scotland's historic environment.

Table 5. Answer of the interviewees to the question "Are you aware of management methodologies to preserve cultural heritage from the implication of climate change?".

\begin{tabular}{ccc}
\hline No & Some Examples * & No Answer \\
\hline $60 \%$ & $15.5 \%$ & $24.5 \%$ \\
\hline \multicolumn{3}{c}{ * See Table 6.}
\end{tabular}

Table 6. Management methodologies known by the interviewees for the incorporation of adaptation to climate change in the preservation of cultural heritage.

\begin{tabular}{cl}
\hline Interviewee & Quotation \\
\hline "I read the one released by UNESCO; (it is) more specific for a natural site more than urban site. It is a really nice \\
methodology because it talks about identifying the vulnerabilities, identifying risks but also identifying what the values \\
are that you have to preserve. That it is a really nice guideline. I think that no one is using it. I haven't seen any report \\
based on that assessment, but maybe there are and I haven't seen them. This is the only one that I am aware of. It comes \\
to UNESCO sites and management for adaptation strategies." \\
"I am aware of a lot of work that (a national heritage authority) did which looks advanced, they have done a lot of work \\
on the understanding of how do we manage the cultural heritage and physical assets under climate change, more rainfall, \\
more wind and so on."
\end{tabular}


The interviewees were aware of examples of best practice in adapting cultural heritage to climate change risks. Their answers were divided into 'managerial and decisional adaptation' and 'practical adaptation' following on the classification previously used in the literature [1]. The best practice examples in managerial and decisional adaptation to climate change were as follows: to increase fundraising, increase the production of knowledge and its dissemination, engage those involved with the heritage (owners, communities, tourists) in adaptation, promote and strengthen monitoring and maintenance, upgrade management plans to include climate change, strengthen regulations and guidelines, keep working on mitigating climate change to reduce future risks (Table 7). Examples of practical adaptation to climate change identified by the interviewees included building defences, using roofs and shelters to protect unroofed sites, upgrading roofs and drainage systems, avoiding the use of incompatible repair materials and surface treatments, moving the heritage sites, monitoring the heritage assets and the climatic conditions, and the use of digital recording (Table 8).

Table 7. Best practice in climate change adaptation identified by the interviewees: managerial and decisional adaptation.

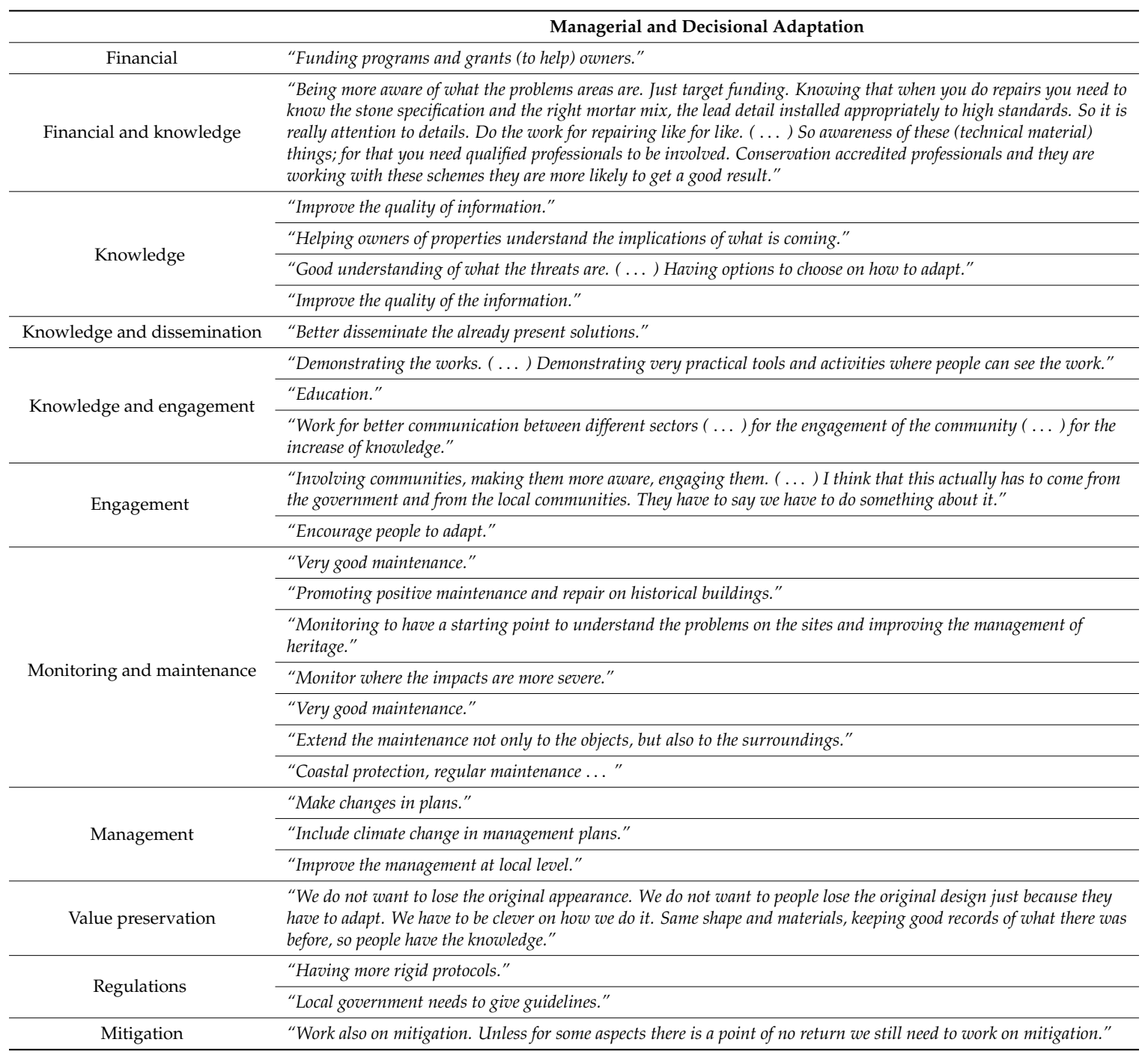


Table 8. Best practice in climate change adaptation identified by the interviewees: practical adaptation.

\begin{tabular}{|c|c|}
\hline & Practical Adaptation \\
\hline \multirow{3}{*}{ Building defences } & "Some sites like Skara Brae there is a sea wall in place for a long time to reduce the amount of coastal erosion." \\
\hline & "Build defences where natural hazards can (impact)." \\
\hline & "Flood defences. Venice is a good example." \\
\hline Roofs and shelters & $\begin{array}{l}\text { "In some archaeological sites they built a roof, a tent, with modern materials on them. I think that there are challenges in how } \\
\text { to do it considering the broader landscape as well." }\end{array}$ \\
\hline \multirow[b]{2}{*}{ Roofs and drainage } & $\begin{array}{l}\text { "Avoiding water penetration in the structures. Maintaining roofs and gutters and other protective layers. Keeping the } \\
\text { structures dry." }\end{array}$ \\
\hline & $\begin{array}{l}\text { "Methods for dealing with water shedding for buildings. If you have heavier individual rainfall events, could be useful to } \\
\text { increase the capacity of the building to shed water quickly. You can make sure that there is a very good maintenance of the roof, } \\
\text { of gutters and downpipes to get rid of water. I am aware that in some cases with increased capacity of gutters and downpipes } \\
\text {... They can't be overwhelmed by the volume of water, otherwise it overflows and can come into the building." }\end{array}$ \\
\hline \multirow{3}{*}{ Drainage } & "Deal with damp penetration and moisture post flood. Increased drainage." \\
\hline & "Adapting the gutters." \\
\hline & "Enlarging the drainage to cope with the increased rainwater." \\
\hline Move & $\begin{array}{l}\text { "Move the heritage. In Norway they are already doing it. The wooden houses close to the coast that are at risk of coastal related } \\
\text { issues have been moved in the (inner) land." }\end{array}$ \\
\hline $\begin{array}{l}\text { Building materials: Avoid } \\
\text { cement mortar }\end{array}$ & $\begin{array}{l}\text { "There are some structures that have particular vulnerabilities to increased rainfall (...) built with impermeable stone like } \\
\text { granite and (...) with cement mortar, and the combination of the impermeable cement mortar and impermeable stone is (... } \\
\text { ) very bad (...) when there is (...) especially (...) heavy rainfall. Because there is no capacity in the building to deal with } \\
\text { penetrating water that tends to come straight to the walls, those types of structure are very vulnerable to increased rainfall. } \\
\text { You can't protect them completely (...) if you had infinite capacity would be to rebuild them without the cement, because if } \\
\text { you use lime mortar, then the wall has more capacity to absorb the rainfall like a sponge. It absorbs the rainfall and then } \\
\text { evaporates later. But with all the cement it comes straight through. But of course you can't take down all these buildings and } \\
\text { rebuild them. In some sites, there are possibilities to do repointing, with a lime mortar that has more capacity to deal with } \\
\text { rainfall that increases the resilience." }\end{array}$ \\
\hline $\begin{array}{l}\text { Building materials: } \\
\text { Harling of surfaces }\end{array}$ & $\begin{array}{l}\text { "(...) harling of surfaces, when you have a stone surface you can cover it with a lime mortar. And quite a lot of buildings } \\
\text { originally have had a lime harling on them, it gives the surface the capacity to deal with rainfall and absorb it, rather than } \\
\text { letting the walls absorb it and hold it, and when it stops raining evaporates. That can increase the resilience of the properties. } \\
\text { Some buildings originally had harling that has been (...) replaced. (...) Tends to be quite controversial to do that because } \\
\text { people tend to be used to the appearance of stones. And people like the appearance of stones (...) (harling) changes the } \\
\text { appearance (of the buildings) and people can be quite resistant to the idea of doing that." }\end{array}$ \\
\hline $\begin{array}{l}\text { Buildings materials: } \\
\text { Avoid moisture barriers }\end{array}$ & $\begin{array}{l}\text { "These kind of water repellents (...) tend to be a disaster. Because water always find a way to come inside. If there are cracks } \\
\text { inside the wall. At the bottom of the wall, water can be dragged on by capillary action. If it is an inhabited building then you } \\
\text { have internal humidity and if you use water repellent barriers on the inside and it is not properly ventilated it keeps the water } \\
\text { inside. So there are always in historical buildings (...) this bad situation. A modern structure tend to be designed with the } \\
\text { use of barriers. (...) But historic buildings cannot work with barriers, because it keeps the problems much worse." }\end{array}$ \\
\hline $\begin{array}{l}\text { Building materials: } \\
\text { New materials }\end{array}$ & "Work for developing new materials that can protect the historical ones. That can be reversible. Test them on case studies first." \\
\hline \multirow[b]{2}{*}{ Monitoring } & $\begin{array}{l}\text { "Keeping regular checks of the conditions of the monuments. ( ... ) regular monitoring ( . . ) make sure that the stonework is } \\
\text { not being destabilised by the loss of mortar and by the decay of the stone." }\end{array}$ \\
\hline & $\begin{array}{l}\text { "Put sensors for the monitoring of temperature, humidity, for estimating a loss of colour in the artefacts, etc. that needs to be } \\
\text { used effectively for the intervention in case of an event. The monitoring has to be "usable" and understandable. (...) In our } \\
\text { site we developed a system for the monitoring of condensation phenomena on frescoes linked with a retro-heating system that } \\
\text { keeps the temperature of the frescos over the condensation point." }\end{array}$ \\
\hline \multirow{2}{*}{ Digital recording } & "Perpetuate the memory of people's life (...) today there is the digital. ( . . ) digitalise it and make it visible to everyone." \\
\hline & "Recording, use high tech digital recording. Scanning." \\
\hline
\end{tabular}

The interviewees were then asked to identify the determinant, or constraining, factors that they consider important for adapting cultural heritage sites to climate change. A list of these factors is provided in Table 9 and categorised into the following groups: (1) Knowledge, education, communication, and awareness; (2) Management, regulations, governance, and drivers; (3) Economic factors; (4) Cultural values; (5) Health and safety concerns; (6) Time. 
Table 9. Determinant factors for adapting cultural heritage to climate change as identified by the interviewees.

\begin{tabular}{|c|c|}
\hline \multicolumn{2}{|r|}{ Determinant Factor for Adapting Cultural Heritage to Climate Change: } \\
\hline $\begin{array}{c}\text { Knowledge, education, } \\
\text { communication and awareness }\end{array}$ & $\begin{array}{l}\text { "Knowledge" } \\
\text { "Lack of example to follow" } \\
\text { "Lack of traditional skills" } \\
\text { "Need for better workforce, need for people trained in traditional skills" } \\
\text { "Knowledge about the traditions and the traditional skills" } \\
\text { "Procurement of traditional materials" } \\
\text { "Proper conservation (knowledge) available for the final users" } \\
\text { "Technologies" } \\
\text { "Lack of definitions" } \\
\text { "Education" } \\
\text { "Make sure that all the stakeholders involved are clear about the co-benefits" } \\
\text { "Knowledge about the history to make people proud" } \\
\text { "Cultural importance of the buildings" } \\
\text { "Information" } \\
\text { "Awareness" } \\
\text { "Communication" } \\
\text { "Translating scientific research into something usable for the stakeholders involved in the maintenance and repair" } \\
\text { "Continue monitoring" } \\
\text { "Having knowledge on how to prepare the plans, maintain the buildings, prepare them for risk, strengthen the } \\
\text { structure and materials" "Manager with technical knowledge" }\end{array}$ \\
\hline $\begin{array}{l}\text { Management, regulations, } \\
\text { governance and drivers }\end{array}$ & $\begin{array}{l}\text { "Need for driver to push people working in government" } \\
\text { "Force people legally to do something" } \\
\text { "A broad regulatory picture" } \\
\text { "Upgrading building regulation to apply to existing buildings" } \\
\text { "Stronger regulation" } \\
\text { "Capacity to get things done. Taking decisions" } \\
\text { "Strong advocacy for the management itself. The management have to protect the authenticity" } \\
\text { "Make sure that climate change is part of the managing plan" } \\
\text { "Clear laws" } \\
\text { "Having management plans related to laws" } \\
\text { "Have politician that understand the issue" } \\
\text { "Cooperation with the communities" } \\
\text { "Cooperation between different levels (e.g., management, local authorities, governmental institutions, etc.)" } \\
\text { "Development of good plans" } \\
\text { "Push from government" } \\
\text { "Collaboration with governmental institutions or with the government" } \\
\text { "Ability of organization" } \\
\text { "Responsibility" } \\
\text { "Willingness of national authorities" } \\
\text { "Rules" } \\
\text { "Standards to follow" } \\
\text { "Trained staff" } \\
\text { "Legislations at political level" } \\
\text { "National legislation" } \\
\text { "European legislation" }\end{array}$ \\
\hline Economic factors & $\begin{array}{c}\text { "Financial limits" } \\
\text { "Incentives" } \\
\text { "Funding programs" } \\
\text { "Financial support from government" }\end{array}$ \\
\hline Cultural values & $\begin{array}{l}\text { "Cultural heritage values" } \\
\text { "Different type of values" } \\
\text { "Acceptance that adaptation is necessary" } \\
\text { "Philosophical constraints" } \\
\text { "Cultural constraints" } \\
\text { "Cultural awareness" }\end{array}$ \\
\hline Health and safety concern & "Health and safety concerns" \\
\hline Time & "Time" \\
\hline
\end{tabular}

\section{Discussion}

The perceptions of experts working in the field of cultural heritage on adaptation to climate change as gathered through semi-structured interviews and a participatory workshop revealed a number of results that are in agreement with the literature, however, issues not previously reported emerged from this study, notably on the opportunities for, and barriers to, adaptation. 


\subsection{Opportunities for Adapting Cultural Heritage to Climate Change}

\subsubsection{Moving from Reactive to Proactive and Planned Adaptation}

The interviewees expressed the need to move from reactive to proactive adaptation. Reactive adaptation is in response to the impact of a climatic event that has already been experienced, for instance a severe storm, landslide, or flood, and often results in short-term planning that aims at returning to conditions as they were prior to the event in question without necessarily aiming to increase the resilience of the site to future events. Proactive or anticipatory adaptation takes place before the occurrence of a climatic event and can be in response to projected changes in climate [44], thereby allowing more time for consultation, the discussion of alternatives, and long-term planning. Such a proactive, planned adaptation involves a policy decision (for cultural heritage this can be a managerial decision) for adapting cultural heritage to changing climatic conditions. During the interactive session of the workshop, some of the participants shared the opinion that moving from reactive to proactive adaptation is feasible: "Long term proactive planning should be compatible with existing mechanisms for ensuring management of heritage sites. It should be possible to factor climate change into existing processes." (Workshop participant, member of a governmental institution). There is still time to "assess, understand and forecast the effects of climate change on cultural heritage in decades to come, before effects are seen, from which relevant mitigation and protection of sites can be developed to prevent a loss of heritage" (Workshop participant, academic). This, however, also constitutes a challenge: "I think there are challenges in getting heritage and other asset managers to take ownership and action on this issue." (Workshop participant, member of governmental institution). Moving from reactive to proactive adaptation is essential to increase resilience at cultural heritage sites to future changes in climatic conditions, including extreme weather events. Once knowing the temporal probability of hazard scenarios, it can be done, for example, beginning with an assessment of the vulnerability of heritage assets or a specific site to understand baseline conditions, monitoring the condition of the site over time frames comparable with ones used by climate scientists in order to minimise natural weather variations, operating continuous maintenance, prioritizing the most vulnerable elements, and planning adaptation options according to projected changes in climate.

\subsubsection{Working on Mitigation and Adaptation Together}

The interviewees indicated the need to pursue efforts aimed at reducing GHG emissions to reduce future risks of climate change on cultural heritage in addition to adapt to the existing and unavoidable risks of a changing climate. There are a number of mitigation actions that can be undertaken in the field of cultural heritage, for example, enhancing energy efficiency in historical buildings, improving the sustainability of interventions in historical buildings, enhancing the reuse of original materials during restoration and refurbishment, and promoting sustainable tourism. Both adaptation of cultural heritage to climate change risks and mitigating climate change to reduce the carbon footprint of heritage buildings are needed and complementary, as well as being recommended by UNESCO [45].

\subsubsection{Strengthening Monitoring and Maintenance}

Many interviewees found that strengthening monitoring and maintenance of cultural heritage is necessary to cope with climate change impacts. The monitoring of climatic conditions and of changes in the condition of heritage assets through surveys, for instance, also creates a baseline dataset against which the impacts of projected changes in climate can be estimated. If a change in decay is predicted as a result of a vulnerability assessment, for instance, it might be possible to manage and mitigate this risk through appropriate maintenance, thereby minimizing or avoiding the damage that would otherwise occur and the need for expensive restoration work. This can be done, for example, by simulating scenarios of possible change in decay with regular time frames, for example every five years, using decay functions and models that use data on material properties, the geometry of the objects and climatic conditions. Such views from cultural heritage experts are consistent with the 
guidelines from UNESCO and ICOMOS, which suggest that long-term programs of monitoring and maintenance should be implemented prior to applying any adaptive measures [19,45]. This is also supported by Sabbioni et al. [1] who recommended more frequent monitoring and maintenance of cultural heritage sites.

\subsubsection{Making Adaptive Change}

There is a dichotomy in the interviewees' perceptions with regard to making adaptive change to cultural heritage. Some see 'change' resulting from adapting cultural heritage to climate change as an opportunity (Table 2) and others perceive it as a challenge (Table 4). When you make changes to cultural heritage there is always the possibility of a conflict between the actions associated with the change and the protected values, integrity, and authenticity of the heritage. A suggestion given by some workshop participants was the development of tools to visualize this 'change' prior to adopting it as a way to predict and argue on the potential decrease in the significance of the cultural and natural heritage (the two are often interconnected) of the protected site. Moreover, such an approach might also avoid the selection of an unsuitable, or not properly studied adaptive solution as mentioned by an interviewee when giving the examples of constructing sea barriers to protect cultural heritage sites located in coastal areas at risk. In Venice, for example, the mobile gates of the MOdulo Sperimentale Elettromeccanico (MOSE) - Italian for Experimental Electromechanical Module—defend the city from sea level rise, high tides, and flooding, and the outcome of such an adaptive solution is overall positive. There are other situations, however, where the selected adaptive solution is inappropriate, for instance, the breakwater barriers built in Agropoli in the Italian province of Salerno led to the proliferation of the Posidonia oceanica algae, which has negative consequences on the marine biodiversity of the area. "It should be known in a better way these technological solutions ... How climate change can have repercussion on the territory?"(Interviewee, researcher). Adopting wrong solutions can lead to a reduction of the multiple values associated with cultural heritage. For instance, decreasing the aesthetic and architectural value of a cultural heritage resource can decrease the interest of tourists with a subsequent decrease in economic and social values or, equally, leading to disinterest of local communities from protecting the heritage site. One could argue that 'adaptive change' can be considered an opportunity only if there is enough research behind the solutions to be adopted both in terms of preservation of heritage values and in terms of the verification of the performance and efficiency of the selected solutions in the long-term.

\subsubsection{Increase Collaboration}

The interviewees emphasized that increased collaboration between different experts, disciplines, institutions and countries presents an opportunity to better implement adaptation strategies. A few interviewees mentioned the lack of communication between different sectors (e.g., academia, government institutions, and local management). Some of the site managers interviewed were not aware of relevant published academic research or of guidelines published in national documents and UNESCO reports. This also highlights a lack of dissemination of the outcomes of academic research and initiatives from government institutions. Collaboration between different actors such as governmental bodies, private individuals, and communities was defined both as a need and as a barrier, the latter when it was non-existent, in the US [28]. International collaboration and cooperation between heritage organizations is promoted by the EC, UNESCO, and ICOMOS [45,46].

\subsubsection{Positivity}

Some interviewees are confident of the possibility to adapt cultural heritage to climate change impacts. The willingness to move forward adaptation of cultural heritage to climate change is a stimulus towards proactive management and hence a determinant factor for the change itself. If people are positive about it, they might invest more resources in proactive adaptation and research. 


\subsection{Requirements for Adapting Cultural Heritage to Climate Change}

\subsubsection{Information on Values, Integrity and Authenticity}

Some interviewees mentioned the need for more information and guidelines on adaptation of cultural heritage to climate change in relation to protecting the values, integrity, and authenticity of cultural heritage. There was a perceived need to investigate further available options to preserve cultural heritage in the context of climate change. Adaptation will possibly be limited if the safeguarding of authenticity, integrity, and value of cultural heritage is considered. "How many changes can you make? How much adaptation can be done to maintain the integrity?" (Interviewee, academic). The problem of altering the authenticity of heritage while restoring it is a perennial problem that cultural heritage faces. This is made difficult by the paucity of practitioners with traditional construction and conservation skills due, in part, to a lack of such training opportunities to architecture and engineering students $[47,48]$. Previous research stresses the need for more technical information and better research on this topic $[27,28]$. Phillips [27] emphasized the difficulty of finding resources and guidance on climate change adaptation and highlighted that the current tools available from national authorities and governmental institutions for climate change adaptation are not used by experts working in cultural heritage.

\subsubsection{Resources}

At the stakeholders' engagement activities, it was noted that more resources (financial, technical, and human) are required to enable adaptation of cultural heritage sites to climate change. More research (and funding for research) was also perceived as a need to inform the adaptation process. Investigating climate change impacts at cultural heritage sites, the monitoring and maintenance of the sites and the implementation of adaptation measures require money, knowledge, skilled people and new technologies. Della Torre [47] stated that adapting means thinking about how to improve the management of heritage sites, not only for monitoring and maintenance but also fundraising, marketing, and protection in view of climate change impacts.

\subsection{Barriers in Adapting Cultural Heritage to Climate Change}

\subsubsection{Diversification}

The interviewees highlighted the difficulty in generalizing adaptation solutions due to the diversity of typologies of cultural heritage, the different geographical locations of heritage assets and the context in which they are located, and the climatic conditions to which they are exposed. This is in addition to the state of decay and the different materials, geometry, and age that characterise cultural heritage assets. As a cultural heritage site is embedded within its environment, one cannot disregard the surrounding landscape in the conservation and valorisation practices [47]. Also, because every site and/or asset has its own cultural, social, and economic values, the interviewees found it difficult to make generalisations on the adaptation practices to be adopted. This supports the view that climate change adaptation requires a case-by-case approach. Nonetheless, there are some types of adaptation practices that can be generalised, for example, strengthening monitoring and maintenance of the sites, and increasing awareness of climate change impacts. Furthermore, adaptation can happen through small steps and at different scales: national (e.g., implementation of regulations), regional (e.g., engagement of population), local (e.g., updating management plans), or done autonomously (e.g., improve regular maintenance and repairs) [19].

\subsubsection{Uncertainty}

A number of interviewees identified the uncertainty in the climate change projections and in the impacts of climate change as well as the effectiveness of the adaptation solutions to deal with those impacts as barriers to adaptation. Existing climate change projections were not known or used by many 
interviewees engaged with the management of heritage sites at the local level. Other interviewees and workshop participants stressed the difficulty in using climate change projections because of the lack of availability of a user-friendly interface and the lack of detailed information provided by the projections. In addition, the lack of information on climate change impacts and uncertainty in the effectiveness of adaptation measures that can be adopted were issues of concern, especially for highly vulnerable sites and where there are limited options for adaptation. The workshop attendees also identified the need for "developing accurate long-term plans and forecasts of the future effects of climate change. [ ... I Understanding how different sites will react to different pressures posed by climate change" (Workshop participant, academic). Uncertainties in climate change projections are commonly referred to as a barrier in the literature. Carmichael et al. [21] mentioned the limited availability of high-confidence climate change projections at the local scale. Phillips [27] also raised the issue of uncertainty in the climate change scenarios as well as the difficulty in interpreting them.

\subsubsection{Resignation}

Some stakeholders expressed despair regarding the possibility to adapt cultural heritage to climate change, because of limitations such as the lack of technologies and resources and low confidence in peoples' willingness for behavioural change, for example, laziness and lack of commitment to mitigate against climate change impacts. It is written in the literature that as long as our heritage is not lost, something can still be done with regard to climate change impacts [1,45]. Preserving our cultural heritage requires a positive and constructive attitude and brings new challenges such as users' engagement (e.g., visitors, staff at cultural heritage sites), research, and management processes, which can be dealt with by adopting cooperative approaches and the co-production of knowledge.

\subsubsection{Loss}

The majority of the interviewees agreed that it is probable that some our cultural heritage will be lost as a result of climate change. This is particularly the case in coastal regions affected by coastal erosion and in regions with melting permafrost. A catastrophic impact would be permanent inundation of coastal heritage cities and sites as a result of sea level rise. The risk of losing part of our heritage because of climate change is exacerbated by the lack of resources available for adaptation, notably financial, human, technical, and time, and the potential disinterest from communities on preserving sites of cultural value in their proximity. The potential loss of cultural heritage as a result of climate change has previously been cited in the literature. Sabbioni et al. [1] stated the need to accept the loss of some of our heritage. UNESCO, for its part, underlined that not all cultural heritage can be saved and that some sites might be abandoned because of the consequences of extreme events [45]. In fact, Marzeion and Levermann [49] estimated that $6 \%$ of UNESCO heritage sites will be impacted by sea level rise over the next two millennia under the projected increase in temperature. Fatorić and Seekamp [28] identified potential loss of cultural heritage as a barrier in terms of "lack of knowledge about letting it go" and in terms of the difficulty from doing so from a managerial perspective. Also, Berenfeld [50] raised the inevitable need for taking 'hard decisions' when selecting which sites to condemn and which sites to preserve.

\subsubsection{Preservation of Values, Integrity and Authenticity}

Strong concerns were expressed by the interviewees regarding the need to adapt to climate change while also preserving the values related to the authenticity and integrity of cultural heritage. This is because some adaptation solutions might sacrifice heritage values or affect the authenticity of the site. An example made by some interviewees was the construction of shelters and roofs over heritage sites, an adaptation solution that can disturb the unity between the heritage object and the landscape, and decrease the authenticity of the archaeological site due to the addition of this non-indigenous element. Another example is the decision to move the heritage site due to its location on an eroding coastline, for instance, which inevitably puts the heritage site out of context, thereby affecting its 
authenticity. Climate change impacts can affect not only the physical cultural heritage, but also the intangible heritage such as memory and history and the societies and communities associated with the tangible cultural heritage [45]. The 'lived experience of culture', the 'identity', 'belonging', and 'sense of place' together with the values, traditions, and cultural practices need to be taken into consideration to determine the acceptability of the climate change adaptation solution [51]. During the workshop the need to engage not only with decision-makers but also with the communities in understanding the heritage values was debated. Some participants mentioned that non-experts in heritage conservation do not often understand the values of a heritage site. The sharing of values of the heritage sites can be accomplished through public engagement and community education on the history and significance of heritage resources. This is consistent with Fatoric and Seekamp [28], who highlighted that experts in cultural heritage preservation from the US expressed concern on the limited understanding of potential changes in the integrity of cultural heritage as a result of climate change adaptation.

\subsubsection{Financial Resources}

The lack of financial resources available to cope with climate change impacts was another issue identified by the interviewees and workshop participants. In heritage sites with high vulnerabilities costly adaptation measures are required, however, institutions and managers in charge of the preservation of cultural heritage sites do not have sufficient financial resources to undertake all required adaptation efforts. It is impossible, for instance, to move all the archaeological sites at risk from coastal erosion. In Scotland only, for example, there are 11,500 coastal archaeological sites [52]. Site prioritization and fundraising strategies are needed to adapt to future climate change. During the workshop the participants stated that physical adaptation is entirely dependent on the economic situation and that more economic funding for technical research is needed. Nonetheless, it was also highlighted that the need for money does not have to be more important than other solutions like public engagement, collaboration, and communication and that decision-making should not be influenced only by the need for finance. Financial resources have also been identified as a barrier to adaptation in the related work of Fatoric and Seekamp's [28] and in Phillips [27] in the US and the UK, respectively.

\subsection{Management Methodologies and Best Practice}

The interviews revealed a lack of awareness of methodologies incorporating climate change adaptation in the management of cultural heritage. This suggests not only the need for further research in this area but also better dissemination of the already available scientific knowledge for its consideration in the management and preservation of cultural heritage sites. This contrasts with reasonably good awareness of best practice in adapting cultural heritage to climate change by the interviewees. In all three countries investigated, adaptation strategies at the governmental level were mentioned during the interviews. In Italy, the national strategy for climate change adaptation recommends the revision of the management plans of cultural heritage sites by introducing specific measures for adapting cultural heritage to climate change [31,32]. It also provides some adaptive solutions to climate change impacts, for example, increasing knowledge, dissemination, monitoring, and maintenance, and delivers a list of best practice in relation to physical adaptation of selected heritage materials (stone, wood and metals). In the UK, HES provides support and guidance on strategies to increase the resilience of Scotland's historic environment [53]. For example, in Curtis and Hunnisett Snow [54] best practice on how to adapt traditional buildings are outlined, such as increasing their resilience through maintenance of building fabric and improvements in the drainage system. In Norway, the Riksantikvaren (Directorate or Cultural Heritage) is committed to the investigation of climate change impacts and the dissemination of adaptation measures to preserve the country cultural heritage from the impacts of climate change [55]. 


\subsection{Best Practice in Adapting Cultural Heritage to Climate Change}

The IPCC identifies four main categories of adaptation measures: technological, behavioural, managerial, and policy. A technological measure to adapt cultural heritage to climate change includes the mobile gates protecting the city of Venice against coastal flooding [56,57]. Changes in the behaviour of tourists and inhabitants living near the protected sites is an example of behavioural adaptation while the monitoring and maintenance of the sites would be considered a managerial measure. Examples of a policy measure are regulations, guidelines, and funding [58,59]. In this paper, the interviewees' answers were divided into two groups: (1) managerial and decisional, which is consistent with the IPCC categories named 'managerial' and 'policy', and (2) practical, which encompasses the 'technological' and 'behavioural' IPCC categories.

The suggested 'managerial and decisional' adaptations included the following:

- Financial resources

- Knowledge of climate change impacts on cultural heritage

- Dissemination of information

- Engagement with stakeholders (e.g., communities and decision-makers)

- Monitoring and maintenance

- Inclusion of climate change in management plans

- Preservation of values

- Regulations and guidelines for adaptation

- Mitigation strategies

The suggested 'practical' adaptations included the following:

- Building coastal defences, roofs, and shelters

- Improving drainage system

- Moving the heritage site

- Avoiding maladaptation such as the inappropriate use of certain building materials and developing new materials compatible with the historic environment

- Improve or strengthen monitoring

- Digital recording of cultural heritage

The examples of climate change adaptations suggested during the stakeholders' consultations are generally in line with the guidelines published in the literature and by governmental organizations. However, there are a few discrepancies in some suggested practical applications in the literature and amongst our interviewees. Some interviewees identified issues with the use of impermeable surface coatings such as water repellents and consolidants on heritage buildings, for instance. This is because with increasing rainfall, walls are likely to retain more moisture and the use of impermeable coatings would reduce the capacity of the excess water to evaporate from the walls. This appears to be a controversial topic with governmental institutions from different countries proposing opposite solutions. In Italy, for example, the use of water repellents and consolidants continue to be promoted as an effective strategy [31]. In contrast, HES states that external waterproof coatings should have breathable properties and thus water repellents and consolidants are not adequate as a long-term solution because they trap moisture inside the walls, thereby causing damage to the stones and bricks typically used in traditional buildings [54]. This does not mean that this adaptive solution should also be unacceptable in Italy, but that a solution in one country could not necessarily be applied in other countries, and that any adaptive option should be contextualized, detailed, and scientifically proved prior to its adoption.

Available research on traditional conservation should be used to validate climate change adaptation options. "One modus operandi or one restrictive set of guidelines or rules are certainly not going to be sufficient to preserve this immense heritage" [19] (p. 120). The scientific community 
should share information, knowledge, and open dialogues to understand the best solution for adaptation. Moreover, the dissemination of information needs to be clear, concise, and easily accessible, and potentially using new technologies to reach different stakeholders. The knowledge needs to be shared not only on best practice for adapting cultural heritage to climate change, but also on the maladaptive actions that can increase further the vulnerability of cultural heritage to climate change [60].

\subsection{Determinant Factors}

The determinant factors that were identified for the implementation of adaptation of cultural heritage to climate change are listed in Figure 1 and could be divided into six groups: (1) Knowledge, education, communication, and awareness; (2) Management, regulations, governance, and drivers; (3) Economic factors; (4) Cultural values; (5) Health and safety concern; and (6) Time (Table 9). This list can be used when planning climate change adaptation in the field of cultural heritage.

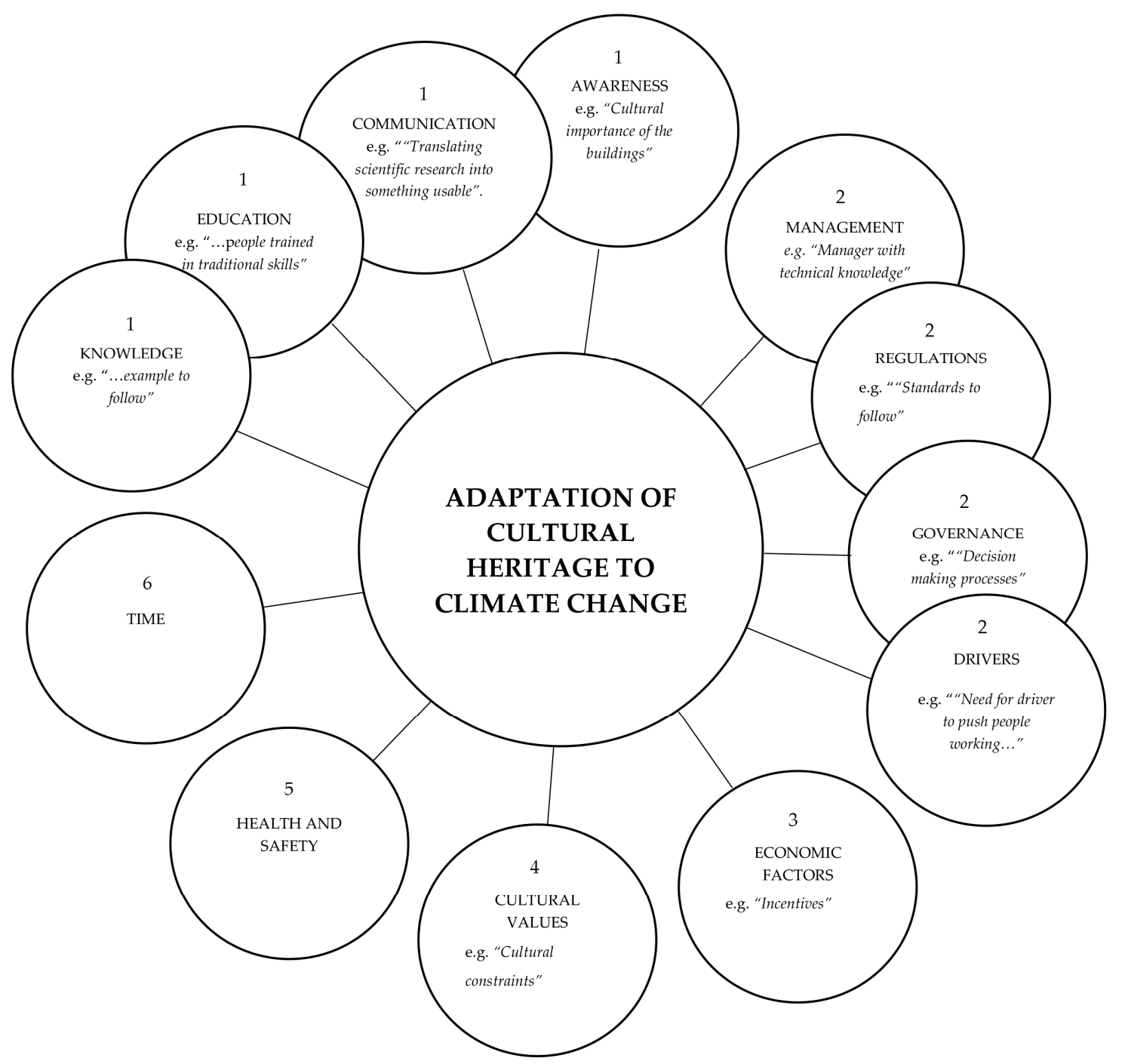

Figure 1. Determinant factors for implementing adaptation of cultural heritage to climate change, as identified by the interviewees. 


\section{Conclusions}

Adaptation of cultural heritage to climate change is necessary to mitigate climate change impacts and to increase the resilience of historical sites. For this reason, organizations such as UNESCO, ICOMOS, IPCC, and the EC recommend more research on this topic. Accordingly, this paper analysed the perceptions of cultural heritage experts on climate change adaptation. Specifically, it reports on how climate change adaptation is considered in the management of cultural heritage sites, in scientific research and by governmental institutions and authorities working in the field of cultural heritage preservation. A common view amongst the interviewees was that adaptation of cultural heritage to climate change is possible. Opportunities for, barriers to, as well as requirements for adapting cultural heritage to climate change, as ascertained by the interviewees, provided a better understanding of what needs to be provided and prioritized for adaptation to take place and in its strategic planning. A lack of knowledge of management methodologies incorporating climate change impacts was reported albeit the interviewees were aware of a number of best practice examples in adapting cultural heritage to climate change. This paper highlights the need for more research and the identification and dissemination of practical solutions and tools for the incorporation of climate change adaptation in the preservation and management of cultural heritage. Figure 2 summarizes the research findings.

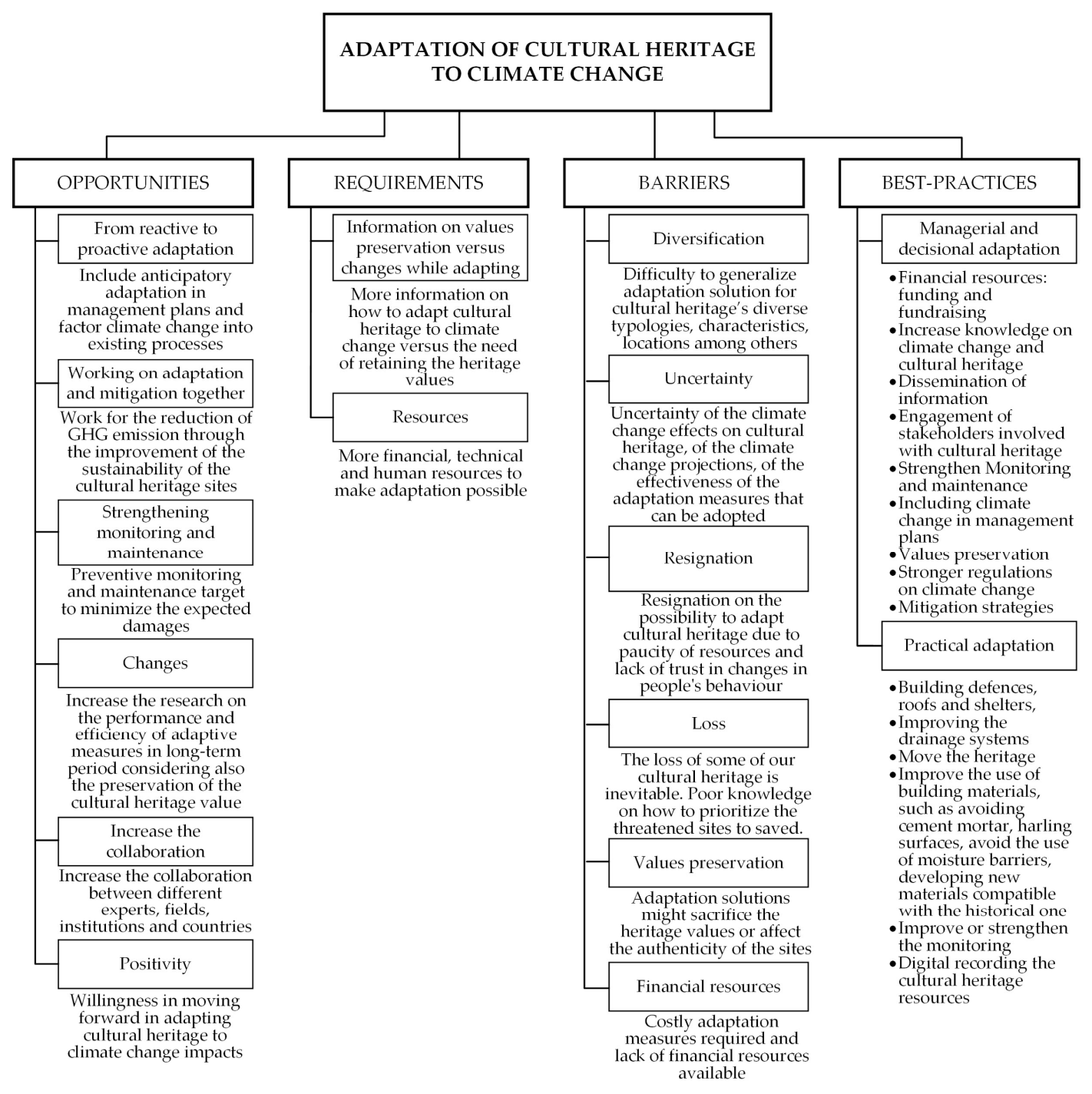

Figure 2. Conceptual diagram depicting the research findings. 
This paper emphasized the complexity of the topic of adaptation of cultural heritage to climate change and the need for further research on this topic. Since the Paris Agreement, UNESCO has aimed to support State Parties in managing climate change impacts, however, State Parties should also collaborate and learn from each other. Adaptive measures developed in one country could be useful and adapted in another country, for instance. Hence the knowledge acquired on climate change adaptation should circulate freely and more developed countries, or countries with strategies, methodologies, measures, and more money for research, should help those that are less fortunate. This requires dialogue and collaboration, however, not only between national governments, but also between heritage organizations, institutions, research centers, heritage site managers, academics, and others involved in the preservation of cultural heritage. There is also an interrupted flow of information between the knowledge available at the international level and the passing of that knowledge down to the local management scale. Another recommendation is mainstreaming climate change in approaches used to manage cultural heritage sites, but this requires awareness of climate change impacts and hence greater dissemination as well as raising awareness of this issue to local communities and increase community engagement, as support from the wider community is important for successful adaptation to climate change. Regulations, the provision of guidelines, and financial incentives are also needed to commit organizations to climate change adaptation. Further research is needed on adaptive measures for specific heritage typologies or materials, mitigation of climate change in field of cultural heritage, and the managing of loss of cultural heritage as a result of inundation of coastal lands, for instance, risk-preparedness and the complexity of making adaptive changes to cultural heritage while also preserving heritage values.

Author Contributions: Conceptualization, E.S., A.G., C.B. and J.H.; Data curation, E.S.; Formal analysis, E.S.; Funding acquisition, E.S., A.G. and J.H.; Investigation, E.S., A.G. and J.H.; Methodology, E.S. and A.G.; Project administration, A.G.; Resources, J.H.; Supervision, A.G., C.B. and J.H.; Validation, C.B.; Visualization, E.S.; Writing — original draft, E.S.; Writing—review \& editing, A.G., C.B. and J.H.

Funding: A university studentship was provided by the University of the West of Scotland to support the doctoral studies of the first author. The Postdoctoral and Early Career Researcher Exchanges (PECRE) funding scheme of the Scottish Funding Council and awarded by the Scottish Alliance for Geoscience, Environment and Society (SAGES) supported the academic exchanges of the first author to Italy and Norway.

Acknowledgments: We thank all the interviewees for their time and information, and Historic Environment Scotland for the grey literature provided. We are also grateful to The Institute of Atmospheric Sciences and Climate, National Research Council of Italy (ISAC-CNR) in Bologna and the Norwegian University of Science and Technology (NTNU) in Trondheim where two academic exchanges were conducted, and to the Scottish Funding Council via the Scottish Alliance for Geoscience, Environment and Society (SAGES) who funded those two academic visits.

Conflicts of Interest: The authors declare no conflict of interest.

\section{References}

1. Sabbioni, C.; Brimblecombe, P.; Cassar, M. The Atlas of Climate Change Impact on European Cultural Heritage: Scientific Analysis and Managment Strategies; Anthem Press: London, UK, 2010.

2. Bertolin, C.; Camuffo, D. Climate Change Impact on Movable and Immovable Cultural Heritage throughout Europe; Damage Risk Assessment, Economic Impact and Mitigation Strategies for Sustainable Preservation of Cultural Heritage in the Times of Climate Change. Available online: https:/ /www.climateforculture.eu/index. php?inhalt=download\&file=pages/user/downloads/project_results/D_05.2_final_publish.compressed.pdf (accessed on 14 August 2018).

3. Leissner, J.; Kilian, R.; Kotova, L.; Jacob, D.; Mikolajewicz, U.; Broström, T.; Ashley-Smith, J.; Schellen, H.L.; Martens, M.; van Schijndel, J.; et al. Climate for culture: Assessing the impact of climate change on the future indoor climate in historic buildings using simulations. Herit. Sci. 2015, 3, 1-15. [CrossRef]

4. Cassar, M. Climate Change and the Historic Environment. Available online: http://unfccc.int/resource/ docs/convkp/conveng.pdf (accessed on 9 August 2018).

5. Brimblecombe, P.; Grossi, C.M.; Harris, I. Climate change critical to cultural heritage. In Survival and Sustainability; Springer: Berlin/Heidelberg, Germany, 2011; pp. 195-205. 
6. United Nations Framework Convention on Climate Change. Available online: http://www. globaldialoguefoundation.org/files/ENV.2009-jun.unframeworkconventionclimate.pdf (accessed on 9 August 2018).

7. Klein, R.; Smith, J. Enhancing the capacity of developing countries to adapt to climate change: A policy relevant research agenda. In Climate Change, Adaptive Capacity and Development; Smith, J., Klein, R., Huq, S., Eds.; Imperial College Press: London, UK, 2003.

8. Smit, B.; Burton, I.; Klein, R.J.T.; Street, R. The science of adaptation: A framework for assessment. Mitig. Adapt. Strateg. Glob. Chang. 1999, 4, 199-213. [CrossRef]

9. Adger, W.N.; Agrawala, S.; Mirza, M.M.Q.; Conde, C.; O’Brien, K.; Pulhin, J.; Pulwarty, R.; Smit, B.; Takahashi, K. Assessment of adaptation practices, options, constraints and capacity. In Climate Change 2007: Impacts, Adaptation and Vulnerability; Contribution of Working Group II to the Fourth Assessment Report of the Intergovernmental Panel on Climate Change; Parry, M.L., Canziani, O.F., Palutikof, J.P., van der Linden, P.J., Hanson, C.E., Eds.; Cambridge University Press: Cambridge, UK, 2007; pp. 717-743.

10. Füssel, H.-M. Adaptation planning for climate change: Concepts, assessment approaches, and key lessons. Sustain. Sci. 2007, 2, 265-275. [CrossRef]

11. Burton, I.; Huq, S.; Lim, B.; Pilifosova, O.; Schipper, E.L. From impacts assessment to adaptation priorities: The shaping of adaptation policy. Clim. Policy 2002, 2, 145-159. [CrossRef]

12. Burton, I. Do we have the adaptive capacity to develop and use the adaptive capacity to adapt? In Climate Change, Adaptive Capacity and Development; Smith, J., Klein, R., Huq, S., Eds.; Imperial College Press: London, UK, 2003; pp. 137-161.

13. Schipper, E.L.F. Conceptual history of adaptation in the UNFCCC process. Rev. Eur. Community Int. Environ. Law 2006, 15, 82-92. [CrossRef]

14. Huq, S.; Reid, H. Mainstreaming adaptation in development. IDS Bull. Banner 2004, 35, 15-21. [CrossRef]

15. Cassar, M.; Pender, R. The impact of climate change on cultural heritage: Evidence and response. In Proceedings of the ICOM Committee for Conservation: 14th Triennial Meeting, The Hague, The Netherlands, 12-16 September 2005; pp. 610-616.

16. Sabbioni, C.; Cassar, M.; Brimblecombe, P.; Lefevre, R.A. Vulnerability of Clultural Heritage to Climate Change; European and Mediterranean Major Hazards Agreement (EUR-OPA); Council of Europe: Strasburgo, France, 2008; pp. 1-24.

17. Heathcote, J.; Fluck, H.; Wiggins, M. Predicting and adapting to climate change: Challenges for the historic environment. Hist. Environ. Policy Pract. 2017, 8, 89-100. [CrossRef]

18. Haugen, A.; Mattsson, J. Preparations for climate change's influences on cultural heritage. Int. J. Clim. Chang. Strateg. Manag. 2011, 3, 386-401. [CrossRef]

19. Cassar, J. Climate change and archaeological sites: Adaptation strategies. In Cultural Heritage from Pollution to Climate Change; Lefèvre, R.-A., Sabbioni, C., Eds.; Edipuglia: Barri, Italy, 2016; pp. 119-127.

20. Pollard-Belsheim, A.; Storey, M.; Robinson, C.; Bell, T. The carra project: Developing tools to help managers identify and respond to coastal hazard impacts on archaeological resources. In Proceedings of the IEEE 2014 Oceans, St. John's, NL, Canada, 14-19 September 2014.

21. Carmichael, B.; Wilson, G.; Namarnyilk, I.; Nadji, S.; Brockwell, S.; Webb, B.; Hunter, F.; Bird, D. Local and indigenous management of climate change risks to archaeological sites. Mitig. Adapt. Strateg. Glob. Chang. 2018, 23, 231-255. [CrossRef]

22. Fatorić, S.; Seekamp, E. Evaluating a decision analytic approach to climate change adaptation of cultural resources along the atlantic coast of the united states. Land Use Policy 2017, 68, 254-263. [CrossRef]

23. Grøntoft, T. Climate change impact on building surfaces and façades. Int. J. Clim. Chang. Strateg. Manag. 2011, 3, 374-385. [CrossRef]

24. Hall, C.M.; Baird, T.; James, M.; Ram, Y. Climate change and cultural heritage: Conservation and heritage tourism in the anthropocene. J. Herit. Tour. 2015, 11, 10-24. [CrossRef]

25. Hall, C.M. Heritage, heritage tourism and climate change. J. Herit. Tour. 2015, 11, 1-9. [CrossRef]

26. Phillips, H. The capacity to adapt to climate change at heritage sites-The development of a conceptual framework. Environ. Sci. Policy 2015, 47, 118-125. [CrossRef]

27. Phillips, H. Adaptation to climate change at UK world heritage sites: Progress and challenges. Hist. Environ. Policy Pract. 2014, 5, 288-299. [CrossRef] 
28. Fatorić, S.; Seekamp, E. Securing the future of cultural heritage by identifying barriers to and strategizing solutions for preservation under changing climate conditions. Sustainability 2017, 9, 2143. [CrossRef]

29. Carmichael, B.; Wilson, G.; Namarnyilk, I.; Nadji, S.; Cahill, J.; Bird, D. Testing the scoping phase of a bottom-up planning guide designed to support australian indigenous rangers manage the impacts of climate change on cultural heritage sites. Local Environ. 2017, 22, 1197-1216. [CrossRef]

30. Casey, A. Climate Change and Coastal Cultural Heritage: Insights from Three National Parks. Available online: https:/ /digitalcommons.uri.edu/oa_diss/745/ (accessed on 9 August 2018).

31. Castellari, S.; Venturini, S.; Giordano, F.; Ballarin Denti, A.; Bigano, A.; Bindi, M.; Bosello, F.; Carrera, L.; Chiriacò, M.V.; Danovaro, R.; et al. Elementi per una Strategia Nazionale di Adattamento ai Cambiamenti Climatici; Ministero dell'Ambiente e della Tutela del Territorio e del Mare: Rome, Italy, 2014.

32. Castellari, S.; Venturini, S.; Pozzo, B.; Tellarini, G.; Giordano, F. Analisi Della Normative Comunitaria e Nazionale Rilevante per gli Impatti, la Vulnerabilità e L'adattamento ai Cambiamenti Climatici; Ministero dell'Ambiente e della Tutela del Territorio e del Mare: Roma, Italy, 2014.

33. Usmanov, B.; Nicu, I.C.; Gainullin, I.; Khomyakov, P. Monitoring and assessing the destruction of archaeological sites from Kuibyshev reservoir coastline, Tatarstan republic, Russian federation: A case study. J. Coast. Conserv. 2018, 22, 417-429. [CrossRef]

34. Nicu, I.C. Cultural heritage assessment and vulnerability using analytic hierarchy process and geographic information systems (Valea oii catchment, north-eastern Romania). An approach to historical maps. Int. J. Disaster Risk Reduct. 2016, 20, 103-111. [CrossRef]

35. Howard, A.J. Managing global heritage in the face of future climate change: The importance of understanding geological and geomorphological processes and hazards. Int. J. Herit. Stud. 2013, 19, 632-658. [CrossRef]

36. Cigna, F.; Tapete, D.; Lee, K. Geological hazards in the UNESCO world heritage sites of the UK: From the global to the local scale perspective. Earth-Sci. Rev. 2018, 176, 166-194. [CrossRef]

37. Smit, B.; Wandel, J. Adaptation, adaptive capacity and vulnerability. Glob. Environ. Chang. 2006, 16, $282-292$. [CrossRef]

38. Lefèvre, R.-A. Resilience and adaptation of cultural heritage to climate change: International workshop in Ravello (Italy) 18-19 May 2017. In Proceedings of the 19th EGU General Assembly (EGU2017), Vienna, Austria, 23-28 April 2017; p. 3308.

39. Convention Concerning the Protection of the World Cultural and Natural Heritage. Available online: http:/ / whc.unesco.org/archive/1995/whc-95-conf202-4reve.pdf (accessed on 14 August 2018).

40. Fatorić, S.; Seekamp, E. Are cultural heritage and resources threatened by climate change? A systematic literature review. Clim. Chang. 2017, 142, 227-254.

41. Michalski, D.J.; Bearman, C. Factors affecting the decision making of pilots who fly in outback Australia. Saf. Sci. 2014, 68, 288-293. [CrossRef]

42. Simonet, G.; Fatorić, S. Does "adaptation to climate change" mean resignation or opportunity? Reg. Environ. Chang. 2016, 16, 789-799. [CrossRef]

43. Poumadère, M.; Bertoldo, R.; Idier, D.; Mallet, C.; Oliveros, C.; Robin, M. Coastal vulnerabilities under the deliberation of stakeholders: The case of two french sandy beaches. Ocean Coast. Manag. 2015, 105, 166-176. [CrossRef]

44. Intergovernmental Panel on Climate Change. Climate Change 2001: Impacts, Adaptation, and Vulnerability; Cambridge University Press: Cambridge, UK, 2001.

45. Colette, A. Climate Change and World Heritage. Report on Predicting and Managing the Impacts of Climate Change on World Heritage and Strategy to Assist States Parties to Implement Appropriate Management Responses; UNESCO World Heritage Centre: Paris, France, 2007.

46. European Commission. Adapting to Climate Change: Towards a European Framework for Action; White Paper; Commission of the European Communities: Brussels, Belgium, 2009.

47. Della Torre, S. Oltre il restauro, oltre la manutenzione. In Proceedings of the International Conference Preventive and Planned Conservation, Monza, Mantova, 5-9 May 2014; pp. 1-10.

48. González Longo, C. Can Architectural Conservation Become Mainstream. Available online: https:/ / strathprints.strath.ac.uk/50220/7/Gonzalez_Longo_ICOMOS_2015_Can_architectural_conservation_ become_mainstream.pdf (accessed on 9 August 2018).

49. Marzeion, B.; Levermann, A. Loss of cultural world heritage and currenlty inhabited places to sea-level-rise. Environ. Res. Lett. 2014, 9, 1-7. [CrossRef] 
50. Berenfeld, M.L. Climate change and cultural heritage: Local evidence, global responses. George Wright Forum 2008, 25, 66-82.

51. Intergovernmental Panel on Climate Change (IPCC). Climate Change 2014: Impacts, Adaptation, and Vulnerability. Part b: Regional Aspects; Contribution of Working Group II to the Fifth Assessment Report of the Intergovernmental Panel on Climate Change; Agard, J., Schipper, E.L.F., Birkmann, J., Campos, M., Dubeux, C., Nojiri, Y., Olsson, L., Osman-Elasha, B., Pelling, M., Prather, M.J., et al., Eds.; Cambridge University Press: New York, NY, USA, 2014; pp. 1757-1776.

52. Daire, M.-Y.; Lopez-Romero, E.; Proust, J.-N.; Regnauld, H.; Pian, S.; Shi, B. Coastal changes and cultural heritage (1): Assessment of the vulnerability of the coastal heritage in western france. J. Isl. Coast. Archaeol. 2012, 7, 168-182. [CrossRef]

53. A Climate Change Action Plan for Historic Scotland 2012-2017. Available online: https://www. historicenvironment.scot/media/2611/climate-change-plan-2012.pdf (accessed on 9 August 2018).

54. Curtis, R.; Hunnisett Snow, J. Climate Change Adaptation for Traditional Buildings; Historic Environment Scotland: Edinburgh, UK, 2016; pp. 1-55.

55. Directorate for Cultural Heritage. Climate Change and Cultural Heritage. Available online: https:/ / edoc. site/ita-2014-world-tunnel-congress-3-pdf-free.html (accessed on 9 August 2018).

56. Anderson, J.; Artale, V.; Breil, M.; Gualdi, S.; Lionello, P. From Global to Regional: Local Sea Level Rise Scenarios Focus on the Mediterranean Sea and the Adriatic Sea; UNESCO: Venezia, Italy, 2010.

57. Mose Project Italy, Immersion of the Chioggia Flood Barrier Caisson. Available online: Availableonlinehttp:/ / www.struktonimmersionprojects.com/news/2013/mose-project-italy--immersion-of-the--chioggia-flood-barrier-caissons/ (accessed on 9 August 2018).

58. Intergovernmental Panel on Climate Change (IPCC). Climate Change 2007: Synthesis Report. Contribution of Working Groups i, ii and iii to the Fourth Assessment Report of the Intergovernmental Panel on Climate Change; IPCC: Geneva, Switzerland, 2007; p. 104.

59. Agrawala, S. The European Alps: Location, economy and climate. In Climate Change in the Alps: Adapting Winter Tourism and Natural Hazard Management; Agrawala, S., Ed.; Organization for Economic and Co-Operation and Development: Paris, France, 2007.

60. Intergovernmental Panel on Climate Change (IPCC). Climate Change 2014: Impacts, Adaptation, and Vulnerability. Part B: Regional Aspects; Contribution of Working Group II to the Fifth Assessment Report of the Intergovernmental Panel on Climate Change; Agard, J., Schipper, E.L.F., Birkmann, J., Campos, M., Dubeux, C., Nojiri, Y., Olsson, L., Osman-Elasha, B., Pelling, M., Prather, M.J., et al., Eds.; Cambridge University Press: New York, NY, USA, 2014; pp. 117-130.

(C) 2018 by the authors. Licensee MDPI, Basel, Switzerland. This article is an open access article distributed under the terms and conditions of the Creative Commons Attribution (CC BY) license (http:// creativecommons.org/licenses/by/4.0/). 